\title{
Extraction Model Of Low Methoxyl Pectin from Apple Pomace Effects of acid concentration and time on the process and the product
}

\author{
Heloísa Cristina Ramos Fertonani ${ }^{1}$, Ardalla Scabio ${ }^{1,2}$, Eliana Beleski Borba Carneiro ${ }^{3}$, \\ Maria Helene Canteri Schemim ${ }^{4}$, Alessandro Nogueira ${ }^{1,5}$ and Gilvan Wosiacki ${ }^{1,6^{*}}$ \\ ${ }^{I}$ Departamento de Engenharia de Alimentos; Universidade Estadual de Ponta Grossa; Av. Carlos Cavalcanti, \\ 4748; 84030-900; Ponta Grossa - PR - Brasil. ${ }^{2} I C$ Scholarship CNPq. ${ }^{3}$ Departamento de Química; Universidade \\ Estadual de Ponta Grossa; Ponta Grossa - PR - Brasil. ${ }^{4}$ Universidade Tecnológica Federal do Paraná; 84016-210; \\ Ponta Grossa - PR - Brasil. ${ }^{5}$ PRODOC Scholarship Capes. ${ }^{6}$ PP Scholarship CNPq
}

\begin{abstract}
In Brazil, one of the top apple producing countries in the world, apple processing is an increasing activity, with pomace as the main by-product. To extract pectin from pomace, factors affecting process and product should be studied for optimization. A model to produce LMP directly from dried apple pomace was established observing the effects of $\mathrm{HNO}_{3}$ concentration and the time of reaction at $97^{\circ} \mathrm{C}$, analyzed from a statistical and practical point of view. The model for gravimetric yield $\left(R^{2}=0.9834\right)$ predicts the highest value of $20.07 \mathrm{~g} / 100 \mathrm{~g}(126 \mathrm{mM} ; 14.07 \mathrm{~min})$ of a pectin with a degree of esterification of $48.49 \%$. The model for degree of esterification of extracted pectin $\left(R^{2}=\right.$ $0.9797)$ predicts the lowest value of $43.73 \%(200 \mathrm{mM} ; 10.07 \mathrm{~min})$ with a yield of $16.77 \mathrm{~g} / 100 \mathrm{~g}$. The results using the central coordinates (100 mM; $10 \mathrm{~min}$ ) for gravimetric yield were $19.01 \mathrm{~g} / 100 \mathrm{~g}$ and for the degree of esterification, $50.79 \%$.
\end{abstract}

Keywords: apple, pectin, extraction, LMP, nitric acid

\section{INTRODUCTION}

Brazilian apple production reaches a level of $1,000.000$ metric ton/year and it is necessary to aggregate some economic value to the so-called industrial fruits $(30 \%)$ by using them as raw material for juice or wine processing (Paganini et al, 2004). Soon there will be a quantitatively expressive amount of a microbiologically unstable by-product, the pomace that dried and powdered can be used as raw material for pectin manufacture (Schemin, Fertonani, Waszczynskyj, Wosiacki, 2005; Marcon, Vriesmann, Wosiacki, Beleski-Carneiro, 2005; Cho, Hwang, 2000, Joshi, Kaushai, 1995). Pectin comprises acidic polysaccharides widely used in food technology as an ingredient for jelly making, among many other purposes (Moorhouse, 2004).

Pectin is a complex heterogeneous polysaccharide found in the primary cell wall of most plants, where it gives mechanical strength and flexibility due to its interaction with other

\footnotetext{
* Author for correspondence: gilvan.wosiacki@ pesquisador.cnpq.br
} 
wall components. As a component of the vegetal cell wall and the intercellular spaces, it may be extracted by acid hydrolysis at a high temperature (Cho, Hwang, 2000). The structure of pectic substances is based on a backbone of polygalacturonic acid stabilized by glycosidic linkage $\alpha(1 \rightarrow 4)$ interspersed by 2-linked Lrhamnosyl residues (Barrett, Northcote, 1965; McNeil, Darvill, Albersheim, 1980). This backbone, known as the "smooth region", is occasionally interrupted by stretches with side chains, which are composed by neutral sugars, mainly arabinose, galactose and rhamnose, the "hairy" region (Rosenbohm, Lundt, Christensen, 2003). The backbone in the "hairy region" has some dimmers composed of alternating $\alpha-\mathrm{D}$ galacturonic acid and $\alpha$-L-rhamnose residues with the arabinan and galactan side chains attached mainly to the 4-position of the methylpentose (Rosenbohm, Lundt, Christensen, 2003). Neutral sugars, as side-chains, are covalently linked to the rhamnogalacturonan at the C-3 of galacturanosyl and/or the C-4 of the rhamnosyl residues (Aspinal, Begbie, Hamilton et al., 1967).The acidic component, or homogalacturonano $\mathrm{HG}$ represented by the polygalacturonic acid, can be partially esterified with methanol and the ratio esterified galacturonic acid : total galacturonic acid is called degree of esterification, $\mathrm{DE} \%$, one of the most important parameters of its quality.

Usually high methoxyl pectin - HMP - is the raw material used to obtain low methoxyl pectin LMP, with controlled acidic hydrolysis (Minkov, Minchev, Paev, 1996; Constenla, Ponce, Lozano, 2003). The establishment of an efficient model for the production of LMP directly from apple pomace, considering the gravimetric yield and the $\mathrm{DE} \%$ as output variables is still necessary to develop further research and development on this subject in the agro-industrial sector.

\section{MATERIAL AND METHODS}

\section{Material}

Apples from the Joaquina variety, harvested in the middle of the 2004/2005 season by trained people in São Joaquim SC, were stored at $+0,5^{\circ} \mathrm{C}$ for one week. After this time, they were used for juice processing at laboratory scale and, after drying and milling, the pomace was considered the raw material for the experiments planned for this report.

\section{Methods \\ Pectin extraction}

Apple pomace powder $(5 \mathrm{~g})$, wetted with $10 \mathrm{ml}$ of $70^{\circ} \mathrm{GL}$ ethanol, was suspended in $100 \mathrm{ml}$ distilled water in a $250 \mathrm{ml}$ Becher. In another Becher, 100 $\mathrm{ml}$ of nitric acid at a concentration such that with a dilution of 1:2 fits the experimental design, was poured. These flasks were put on a heating plate and when both reached the boiling point, the nitric acid solution was poured into the pomace suspension with vigorous stirring and the time of extraction, previously defined by the experimental design, was rigorously respected before stopping the reaction in ice-cold water bath. After cooling, acid soluble compounds were filtered trough a cheese cloth, the residue being rinsed twice with $100 \mathrm{ml}$ distilled water (Fertonani et al, 2005, Schemin et al., 2005; Marcon et al, 2005;).

\section{The precipitation of pectic substances}

The acid soluble pectic compounds were precipitated by dropping them carefully with slow stirring in ethyl alcohol, reaching a final proportion 1:3 (v/v) and after a resting time the flocculating material was removed through cheese cloth filtration, and left in alcohol $70 \%$ overnight to remove excess acid by simple diffusion. The hydro-alcoholic liquid was then removed by squeezing pectic substances against filter paper, drying them firstly with cold air $\left(30^{\circ} \mathrm{C}\right)$ and then with hot air $\left(60^{\circ} \mathrm{C}\right)$. Dried powdered pectin was stored at room temperature in silica gel-containing flasks (Schemin et al., 2005).

\section{Gravimetric yield}

The yield of the extraction and isolation of the pectic substances from apple pomace was calculated as the gravimetric ratio of driedpowdered pectin: dried pomace, in $\mathrm{g} \%$.

\section{Degree of esterification}

The esterification degree was calculated as the ratio of methoxyl-anhydro-galacturonic acid : total anhydro-galacturonic acid, determined titrimetrically with $\mathrm{NaOH} \quad 0,1 \mathrm{~N}$ (Bochek, Zabivalona, Petropavlowskii, 2001.) with the use of phenolphthalein. The figures were corrected to a pure acidic polysaccharide, considering that an esterification degree of $100 \%$ corresponds to a methoxyl content of 16\% (Kertesz, 1951). 
The pectin was also characterized by Fourier transform spectra (FT-IR), with specific peaks at 1741.6 and $1633.6 \mathrm{~cm}^{-1}$ since the former correspond to methoxyl-anhydro-galacturonic acid and the later, to non esterified galacturonic acid. The degree of esterification was calculated as the ratio of the area under the peak at $1741.6 \mathrm{~cm}^{-1}$ and by the area corresponding to total galacturonic acid, with the software of the spectrophotometer (Monsoor, Kalapathy, Proctor, 2001).

\section{Experimental design}

The experimental design was a central composite factorial $2^{2}$ axial with a triplicate at the central point (Barros Netto, Scarminio, Bruns, 2004). Input variables were nitric acid concentration and time of reaction at boiling temperature of the system (200 ml/500 ml flasks). The dependent variables were gravimetric yield in $\mathrm{g} .100 \mathrm{~g}^{-1}$ and degree of esterification, DE, in \%. The statistic interpretation of the data was done using the tool analysis from STATISTIC ${ }^{\circledR}$ software as well as that from Barros Neto, Scarmínio, Bruns (2004). The experimental domain is shown in Table 1 and description of the assays in Table 2, respectively. The essays 1-4 correspond to the cubic set, the 5-7, to the central triplicate point and 8-11, to the axial or quadratic set.

Table 1 - Establishing the experimental domain.

\begin{tabular}{ccccccc}
\hline \multicolumn{2}{c}{ Input Variables } & \multicolumn{5}{c}{ Values } \\
\hline Coded & $\mathbf{X}_{\mathbf{1}} \mathbf{X}_{\mathbf{2}}$ & $\mathbf{- 1 . 4 1 4}$ & $\mathbf{- 1}$ & $\mathbf{0}$ & $\mathbf{+ 1}$ & $\mathbf{+ 1 . 4 1 4}$ \\
\hline Decoded & $\begin{array}{c}\mathrm{HNO}_{3} \\
\mathrm{mM}\left(\mathrm{a}_{1}\right)\end{array}$ & 8.0 & 35 & 100 & 165 & 192 \\
$\begin{array}{c}\text { Time } \\
\mathrm{min}\left(\mathrm{a}_{2}\right)\end{array}$ & 2.7 & 5 & 10 & 15 & 17.3 \\
\hline
\end{tabular}

The coded and decoded values can be obtained by the expression

$$
\mathrm{X}_{\mathrm{i}}=\frac{\left(\mathrm{a}_{\mathrm{i}}-\mathrm{X}_{\mathrm{i}} 0\right)}{\triangle \mathrm{X}_{\mathrm{i}}}
$$

where $X_{i}$ is the coded value, $\underline{a}_{i}$ is the corresponding actual value, $X_{i}^{0}$ is the actual value in the center of domain and $\triangle X_{i}$ is the increment of $\underline{X}_{i}$ corresponding to 1 unit. $X_{1}$ (coded value of extraction time), $X_{2}$ (coded value of temperature), $\mathrm{X}_{3}$ (coded value of nitric acid concentration) were given by equations $(2,3)$.

$$
X i=\underline{\left(a_{1}-100\right)} \frac{\text { (2) }}{35} \quad \text { X2 }=\underline{\left(a_{2}-10\right)}
$$

Table 2 - Decoding the experimental design.

\begin{tabular}{ccccc}
\hline Run & $\mathbf{X}_{\mathbf{1}}$ & $\mathbf{X}_{\mathbf{2}}$ & $\mathbf{H N O}_{\mathbf{3}} \mathbf{m M}$ & Time,min \\
\hline 1 & -1 & -1 & 35 & 5 \\
2 & -1 & +1 & 35 & 15 \\
3 & +1 & -1 & 165 & 5 \\
4 & +1 & +1 & 165 & 15 \\
5 & 0 & 0 & 100 & 10 \\
6 & 0 & 0 & 100 & 10 \\
7 & 0 & 0 & 100 & 10 \\
8 & -1.414 & 0 & 8 & 10 \\
9 & +1.414 & 0 & 192 & 10 \\
10 & 0 & -1.414 & 100 & 2,7 \\
11 & 0 & +1.414 & 100 & 17,3 \\
\hline
\end{tabular}




\section{The model}

The second-order polynomial regression model is represented as follows:

$\mathrm{Y}_{\mathrm{n}}=\mathrm{b}_{0}+\mathrm{b}_{1} \mathrm{X}_{1}+\mathrm{b}_{2} \mathrm{X}_{2}+\mathrm{b}_{11} \mathrm{X}_{1}^{2}+\mathrm{b}_{22} \mathrm{X}_{2}^{2}+\mathrm{b}_{12} \mathrm{X}_{1} \mathrm{X}_{2}(4)$

where $Y_{n}$ represents the response variables, $b_{0}$, the intercept, $b_{n}$, the regression coefficients and $X_{n}$, the independent variables. Such model may be adjusted by canceling the components whose standard error is high and probability $(p)$ is higher than $5 \%$.

\section{RESULTS AND DISCUSSION}

When a hot dilute nitric acid solution is poured on powdered apple pomace it promotes many hydrolytic reactions, disrupting plant cell walls and liberating acid soluble pectin with bounded neutral sugar chains. The acid concentration, temperature and time are factors that may also promote the degradation of the polysaccharides themselves and so it is necessary to monitor the assay conditions to drive the balance of the positive reactions, releasing the acid soluble polymers, with the negative reactions, hydrolyzing the glycoside and the ester groups.

The mathematical models for acid extraction of pectin from powdered apple pomace and for the determination of its esterification degree, in a quantitative and qualitative approach, respectively, are here reported concerning their statistical and practical significance.

\section{The models and their statistical significance Modeling the acid extraction of pectin - a quantitative measurement}

In Table 3 it is shown the figures obtained by following the experimental design as well as those predicted by the model and the residue, which is the difference between both sets. The run made in triplicate was used to determine the standard deviation, of 0.3579 . The plot real $\mathrm{x}$ predicted values for gravimetric yield results in a straight line with a determination coefficient of $98.98 \%$.

Table 3 - Model for gravimetric yield in practice and in theory.

\begin{tabular}{cccc}
\hline Run & Actual & $\begin{array}{c}\text { Gravimetric yield, } \mathbf{g} \% \\
\text { Predict }\end{array}$ & Residue \\
\hline 1 & 11.87 & 11.49 & 0.376 \\
2 & 14.88 & 15.28 & -0.408 \\
3 & 17.18 & 16.96 & 0.214 \\
4 & 18.54 & 19.11 & -0.570 \\
5 & 19.26 & 19.01 & 0.249 \\
6 & 18.60 & 19.01 & -0.410 \\
7 & 19.17 & 19.01 & 0.159 \\
8 & 10.75 & 10.76 & -0.017 \\
9 & 17.55 & 17.33 & 0.211 \\
10 & 14.82 & 15.27 & -0.458 \\
11 & 20.13 & 19.47 & 0.652 \\
\hline
\end{tabular}

In Table 4 it is shown the model for acid extraction of pectin in which the main effects are from the $\mathrm{HNO}_{3}$ concentration, both in linear and quadratic form, although time influence is also relevant. The interrelation acid concentration and time shows a small influence in the model, as can be verified in its high standard error. The negative coefficient for both quadratic terms points to a surface with a maximum stationary value.

The analysis of variance show a regression highly significant $\left(\mathrm{F}_{\mathrm{ca}} / \mathrm{F}_{\mathrm{tab}}=11,79\right)$ with a low lack of fit
$(0,18)$ and explaining $98,35 \%$ from the total of $99,74 \%$ explainable variance.

In Figure 1 it is possible to observe the effect of acid concentration and of the time. It should be emphasized that when climbing the hill there is more extraction than degradation of pectin and at the top both reactions are balanced, in equilibrium. The 2D projection of the response surface is useful to figure out the coordinates for the highest value of gravimetric yield of pectin. 
Table 4 - The model of acid extraction of pectin.

\begin{tabular}{ccccccc}
\hline Factors & $\begin{array}{l}\text { Regression } \\
\text { coefficients }\end{array}$ & Standard error & $\mathrm{t}(5)$ & $\mathrm{P}$ & $\begin{array}{c}\text { Confidence } \\
\text { Limit -95\% }\end{array}$ & $\begin{array}{c}\text { Confidence } \\
\text { Limit }+95 \%\end{array}$ \\
\hline Mean & 19.01 & 0.33 & 57.90 & 0.00000 & 18.16 & 19.85 \\
$\mathrm{X}_{1}(\mathrm{~L})$ & 2.32 & 0.20 & 11.55 & 0.00008 & 1.80 & 2.84 \\
$\mathrm{X}_{1}(\mathrm{Q})$ & -2.48 & 0.24 & -10.35 & 0.00014 & -3.09 & -1.86 \\
$\mathrm{X}_{2}(\mathrm{~L})$ & 1.48 & 0.20 & 7.38 & 0.00071 & 0.96 & 2.00 \\
$\mathrm{X}_{2}(\mathrm{Q})$ & -0.81 & 0.24 & -3.41 & 0.019 & -1.43 & -0.20 \\
$1 \mathrm{~L}$ by $2 \mathrm{~L}$ & -0.41 & 0.28 & -1.45 & 0.21 & -1.14 & 0.32 \\
\hline
\end{tabular}

$\mathrm{R}^{2}=0.98348$; Adjustment $=0.96696$; MS Residual $=0.3233428$

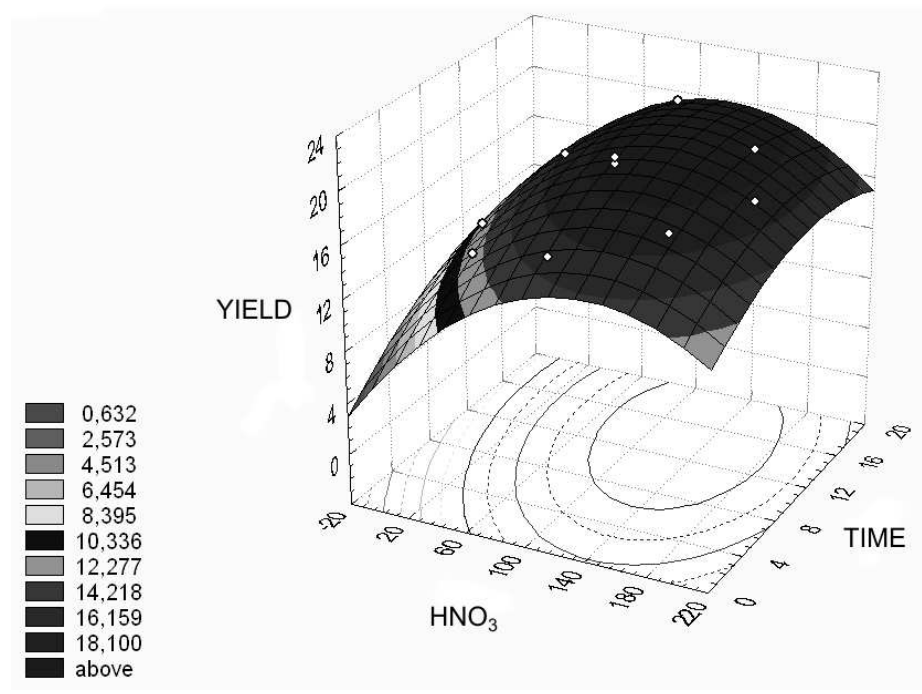

Figure 1 - Effect of HNO3 concentration and of time on gravimetric yield as shown in a 3D response surface and its $2 \mathrm{D}$ projection.

\section{Modeling the esterification degree $-a$ qualitative measurement}

In Table 5 it is shown the figures obtained with the experimental design as well as the one predicted by the model and the residue, which is the difference between both sets. The run made in triplicate was used to determine the standard deviation, of 1.979. The plot real $\mathrm{x}$ predicted values for the esterification degree shows a linear array with a determination coefficient of $97.93 \%$.

In Table 6 is shown the coefficients of the model for the esterification degree of extracted pectin and the main effects were observed in $\mathrm{HNO}_{3}$ concentration, both in linear and quadratic form, although time influence is also relevant, especially in the quadratic aspect. The linear term of time and the interaction acid concentration and time show small influences in the model, as can be judged by their high standard error. The positive coefficient for both quadratic terms points to a surface with a minimum stable stationary point. The analysis of variance show a regression highly significant $\left(\mathrm{F}_{\mathrm{cal}} / \mathrm{F}_{\mathrm{tab}}=9.54\right)$ with a low lack of fit $(0,0329)$ and explaining $97.97 \%$ from the total of $97.97 \%$ explainable variance.

In Figure 2 it is possible to observe the high negative effects of the acid concentration and of the time on the behavior of esterification degree as expected because the conditions favors the demethoxylation reaction, which transforms HMP in LMP. The 2D projection of the response surface is also useful to define the coordinates of the stationary point where the lowest value of esterification degree of extracted pectin can be found. 
Table 5 - DE in practice and in theory.

\begin{tabular}{cccc}
\hline \multirow{2}{*}{ Run } & Ectual & $\begin{array}{c}\text { Esterification degree, \% } \\
\text { Predict }\end{array}$ & Residue \\
\hline 1 & 67.57 & 67.09 & +0.479 \\
2 & 64.36 & 63.79 & +0.562 \\
3 & 49.55 & 48.33 & +1.215 \\
4 & 47.73 & 46.43 & +1.298 \\
5 & 48.61 & 50.78 & -2.176 \\
6 & 52.48 & 50.78 & +1.693 \\
7 & 51.27 & 50.78 & +0.483 \\
8 & 69.01 & 69.37 & -0.368 \\
9 & 42.43 & 43.84 & -1.409 \\
10 & 57.22 & 58.05 & -0.830 \\
11 & 53.43 & 54.37 & -0.947 \\
\hline
\end{tabular}

Table 6 - The model of esterification degree of pectin.

\begin{tabular}{ccccccc}
\hline Factors & $\begin{array}{c}\text { Regression } \\
\text { coefficients }\end{array}$ & Standard error & $\mathrm{t}(5)$ & $\mathrm{P}$ & $\begin{array}{c}\text { Confidence. } \\
\text { Limit -95\% }\end{array}$ & $\begin{array}{c}\text { Confidence. } \\
\text { Limit 95\% }\end{array}$ \\
\hline Mean & 50.79 & 1.01 & 50.33 & 0.00 & 48.19 & 53.38 \\
X1(L) & -9.03 & 0.62 & -14.62 & 0.00 & -10.62 & -7.44 \\
X1(Q) & 2.91 & 0.74 & 3.96 & 0.01 & 1.02 & 4.80 \\
X2(L) & -1.30 & 0.62 & -2.10 & 0.09 & -2.89 & 0.29 \\
X2(Q) & 2.71 & 0.74 & 3.69 & 0.01 & 0.82 & 4.61 \\
1L by 2L & 0.35 & 0.87 & 0.40 & 0.71 & -1.90 & 2.59 \\
\hline
\end{tabular}

R2=0.9797; Adjustment=0.9593; MS Residual=3.0542

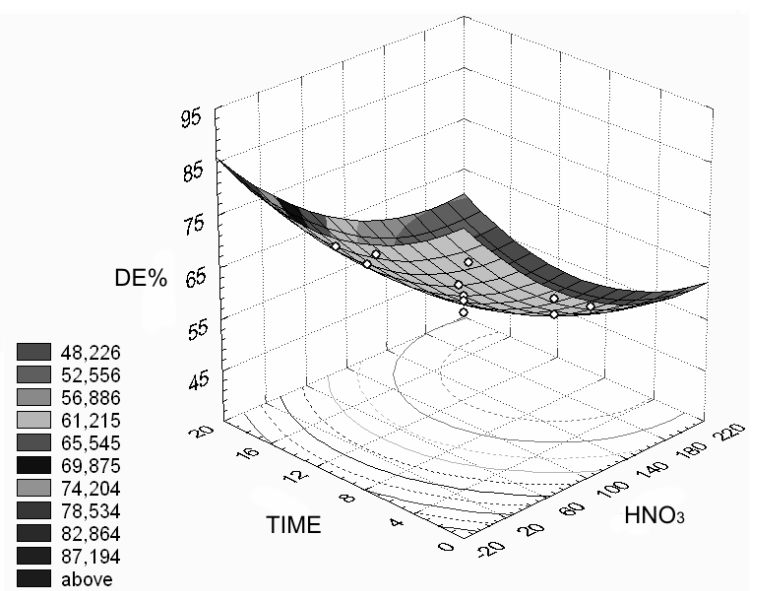

Figure 2 - Effect of $\mathrm{HNO}_{3}$ concentration and of time on the degree of esterification as shown in a $3 \mathrm{D}$ response surface and its $2 \mathrm{D}$ projection.

\section{The models and their practical significance}

The second-order polynomial regression model for gravimetric yield is shown as follows with all its components (equation 5) as well as the adjusted form (equation 6)

Yield $=19.01+2.32 * \mathrm{X} 1-2.48 * \mathrm{X} 1 * \mathrm{X} 1+1.49 * \mathrm{X} 2-$ $0.82 * \mathrm{X} 2 * \mathrm{X} 2-0.41 * \mathrm{X} 1 * \mathrm{X} 2$
Yield $=19.01+2.32 * \mathrm{X} 1-2.48 * \mathrm{X} 1 * \mathrm{X} 1+1.49 * \mathrm{X} 2-$

$$
0.82 * \mathrm{X} 2 * \mathrm{X} 2
$$

The second-order polynomial regression model for degree of esterification is shown as follows with 
all its components (equation 7) as well as the adjusted form (equation 8 )

$\mathrm{DE}=50.79-9.03 * \mathrm{X} 1+2.91 * \mathrm{X} 1 * \mathrm{X} 1-$ $1.30 * \mathrm{X} 2+2.71 * \mathrm{X} 2 * \mathrm{X} 2+0,346 * \mathrm{X} 1 * \mathrm{X} 2$

$\mathrm{DE}=50.79-9.03 * \mathrm{X} 1+2.91 * \mathrm{X} 1 * \mathrm{X} 1+2.71 * \mathrm{X} 2 * \mathrm{X} 2$

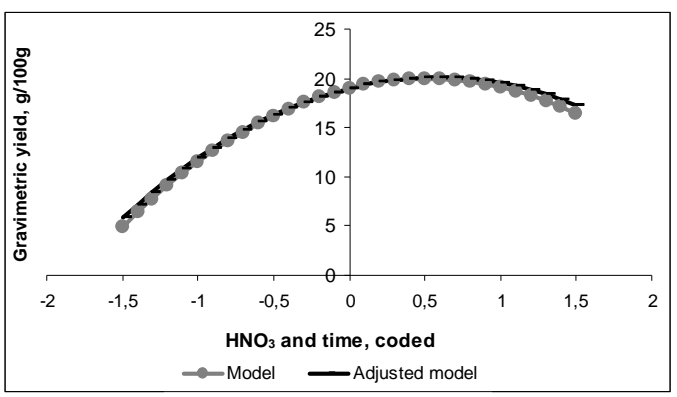

(A) Effect of simultaneously increase in time and acid concentration, maintaining the temperature at central level, in the gravimetric yield, $\mathrm{g} / 100 \mathrm{~g}$.
In the Figure $3(\mathrm{~A})$ is shown the effect of time and acid concentration increase simultaneously on the gravimetric yield as predict by the model and its adjusted form. The lines are almost the same since only the interaction between both factors is not significant. Similar results were found for degree of esterification (Figure $3 \mathrm{~B}$ ).

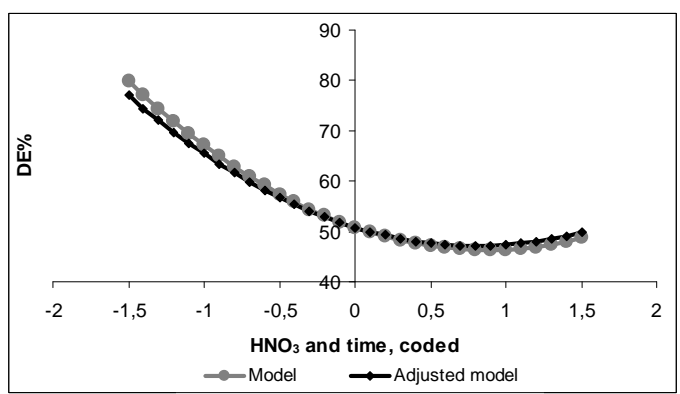

(B) Effect of simultaneously increase in time and acid concentration, maintaining the temperature at central level, in the degree of esterification, $\%$.

Figure 3 - Gravimetric yield and degree of esterification as seen by the model and adjusted model.

The extraction and the quality of pectin is directly related to the kind and to the acid concentration, to the temperature and to the time of the reaction and the models here reported should predict the amount and the degree of esterification of the products. In Table 9 are shown the predict values by the models. The model for the gravimetric yield of pectin was used to find the coordinates of the stationary point that represents a maximum value since both quadratic coefficients are negative. Maximum yield of pectin was $20.07 \mathrm{~g} / 100 \mathrm{~g}$ when $\mathrm{HNO}_{3}$ concentration was $126 \mathrm{mM}$ and time of reaction was $14.07 \mathrm{~min}$. The esterification degree, calculated by the proper model, should be $48.49 \%$. Such conditions are not too far from the central experimental coordinates.

The model for the esterification degree of pectin was used to find the coordinates of the stationary point that represent a minimum value, since both quadratic coefficients are positive. The minimum esterification degree of pectin was $44.3 \%$ when $\mathrm{HNO}_{3}$ concentration was $200 \mathrm{mM}$ and time of reaction was $10.07 \mathrm{~min}$. At that coordinates the model for gravimetric yield predicts a value of $16.77 \mathrm{~g} / 100 \mathrm{~g}$. In the coordinates $100 \mathrm{mM}$ and 10 min the expected value of $19.01 \mathrm{~g} / 100 \mathrm{~g}$ is not too far from that predicted as maximum, $20.07 \mathrm{~g} / 100 \mathrm{~g}$, since it represents a difference of less $5 \%$, although both values are categorized in two contiguous levels in a $2 \mathrm{D}$ projection of the response surface. It must be stressed that the sensibility of practical procedures is far behind that of the theoretical ones as can be seen by the standard deviation of the central essays made in triplicate.

There is a large distance between both sets of coordinates representing the stationary points of both models and best results were found in the coordinates choose as the central run of the experimental design because there is a high gravimetric yield $(19.01 \mathrm{~g} / 100 \mathrm{~g})$ of a LMP $(50.78 \%)$. It should be mentioned that such conditions should provide less degraded pectin with an esterification results closer to $50 \%$.

Table 7 - Predicted values in special coordinates.

\begin{tabular}{cccccc}
\hline \multicolumn{2}{c}{ Coded variables } & \multicolumn{2}{c}{ Decoded variables } & $\begin{array}{c}\text { Yield } \\
\text { g/100g }\end{array}$ & DE \% \\
\hline $\mathrm{X} 1$ & $\mathrm{X} 2$ & $\mathrm{HNO}^{3} \mathrm{mM}$ & Time min & & \\
0 & 0 & 100 & 10 & 19.01 & 50.78 \\
0.400 & 0.814 & 126 & 14.07 & 20.07 & 48.49 \\
1.546 & 0.140 & 200 & 10.07 & 16.77 & 43.73 \\
\hline
\end{tabular}




\section{Qualifying the sample}

The pectin sample obtained at the coordinates 100 $\mathrm{mM}$ and $10 \mathrm{~min}$ was analyzed by means of titrimetric and FT-IR techniques and compared to a commercial sample of LMP. In Table 8 it is shown the titrimetric features of the analyzed samples considering only the acidic or homogalacturonan fraction from a chemical point of view, and the experimental pectin has all values compatible with that from commercial LMP. In Figure 4 is shown the spectra obtained in the range $4000-400 \mathrm{~cm}^{-1}$, for both samples with a quite similar profile concerning the 2 peaks at 1741.6 and $1633.6 \mathrm{~cm}^{-1}$, related to esterified and non esterified carboxyl groups, respectively (Marcon, 2004), at the same intensity, suggesting a similar degree of esterification. Indeed, it was considered the ratio of the area related to esterified carboxyl groups and total carboxyl groups and the result was a $51 \%$ for the experimental sample and $49 \%$ for the commercial LMP sample.

Table 8 - Titrimetric quality of commercial pectin and experimental LMP.

\begin{tabular}{cccc}
\hline & AUA, \%* & MEO, \%* & DE, \% \\
\hline Commercial HMP & 87.89 & 12.11 & 75.70 \\
Commercial LMP & 92.11 & 7.89 & 49.34 \\
Experimental pectin & 91.84 & 8.16 & 50.98 \\
\hline
\end{tabular}

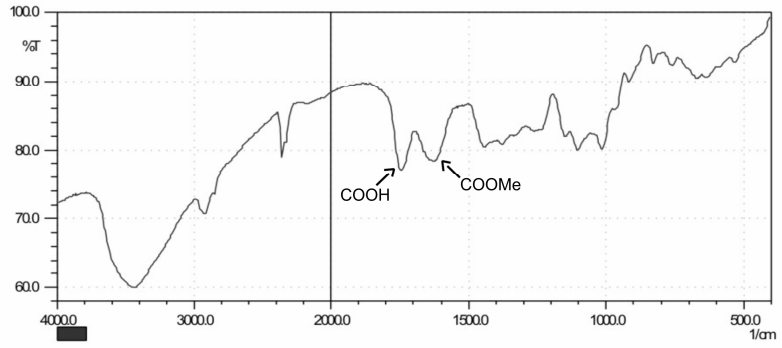

(A)

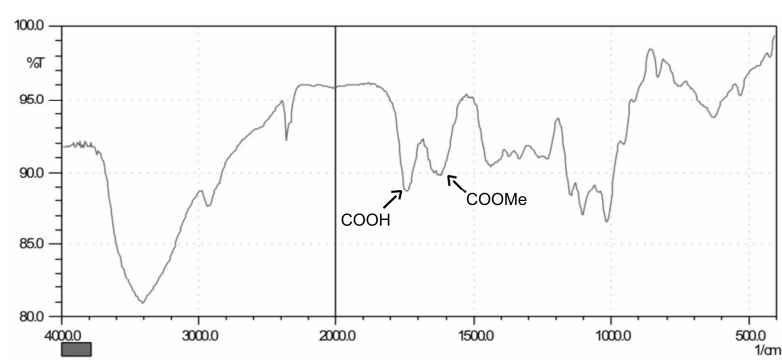

(B)

Figure 4 - LMP extracted in $100 \mathrm{mM} \mathrm{HNO}_{3}$ during $10 \mathrm{~min}$, with $51 \% \mathrm{DE}$ (A) and LMP commercial sample, with $49 \%$ DE (B).

\section{CONCLUSION}

The model for the extraction of pectin from apple pomace powder determines the coordinates of the stationary point, the values of $126 \mathrm{mM} \mathrm{HNO}_{3}$ and $14.07 \mathrm{~min}$ to reach the maximum yield of 20.07 $\mathrm{g} / 100 \mathrm{~g}$. As for the esterification degree, the coordinates were $200 \mathrm{mM} \mathrm{HNO}_{3}$ and $10.07 \mathrm{~min}$ to reach a minimum of $43.73 \%$, but this stationary point is outside the experimental domain.

The model of acid solubilization of protopectin confirms that $10 \mathrm{~min}$ is a satisfactory time period for $\mathrm{HNO}_{3} \mathrm{mM}$ to reach a gravimetric yield of $19.01 \mathrm{~g} / 100 \mathrm{~g}$ of apple pomace of a low methoxyl pectin $(\mathrm{DE}=50.78 \%)$ as a final product.

\section{ACKNOWLEDGMENT}

The authors are deeply grateful to UEPG and GTM (www.pitangui.uepg.br/gtm), for the facilities available in the laboratory, to CNPq and CAPES, for scholarships and to Epagri, for the apple cv. Joaquina given.

\section{RESUMO}

No Brasil, um dos países com alta produção de maçã, o seu processamento é uma atividade em crescimento tendo o bagaço como principal subproduto. Para extrair pectina do bagaço os fatores que afetam o processo e o produto devem ser otimizados. Um modelo para extrair LMP foi estabelecido observando os efeitos de concentrações de $\mathrm{HNO}_{3}$ e do tempo de reação a $97^{\circ} \mathrm{C}$, analisados estatística e praticamente. O modelo para o rendimento $\left(\mathrm{R}^{2}=0,9834\right)$ prediz o mais elevado valor de 20,07 g/100 g (126 mM; 14,07 min) de pectina com grau de esterificação de $48,49 \%$. O modelo para o grau de esterificação de 
pectina extraída $\left(\mathrm{R}^{2}=0,9797\right)$ prediz o mais baixo valor de 43,73\% (200 $\mathrm{mM}$; 10,07 $\mathrm{min}$ ) com um rendimento de $16,77 \mathrm{~g} / 100 \mathrm{~g}$. Os resultados usando as coordenadas do ponto central $(100 \mathrm{mM} ; 10 \mathrm{~min})$ para o rendimento foram $19,01 \mathrm{~g} / 100 \mathrm{~g}$ e para o grau de esterificação, $50,79 \%$.

\section{REFERENCES}

Aspinal,G.O., Begbie,R., Hamilton,A. (1967), Polysaccharides of soy-beans .3. Extraction and fractionation of polysaccharides from cotyledon meal. Journal of the Chemical Society C-Organic, 11, 1065.

Barrett,A.J.; Northcot,D.H. (1965), Apple fruit pectic substances. Biochemical Journal, 94, 617.

Barros Neto,B.; Scarminio,I.S.; Bruns,R.E. (1995), "Planejamento e otimização de experimentos". Editora da Unicamp: Campinas. 299.

Bochek,A.M.; Zabivalona,N.M.; Petropavlowskii, G.A. (2001), Determination of the esterificatiton degree of polygalacturonic acid. Russian Journal of Applied Chemistry, 74, 796-799.

Cho,Y.-J.; Hwang,J.-K. (2000), Modeling the yield and intrinsic viscosity of pectin in acidic solubilization of apple pomace. Journal of Food Engineering, 44, 85-89.

Constenla,D; Ponce,A.G.; Lozano,J.E.(2003), Kinetic model of pectin demethylation. Latin American Applied Research, 33, 91-96.

Fertonani, H.C,R, Scabio,A., Schemin,M.H.C., Carneiro,E.B.B., Nogueira, A., Wosiacki,G.(2006) Influência da concentração de ácidos no processo de extração e na qualidade de pectina de bagaço de maçã. Semina: Ciências Agrárias, Londrina, 27, 617630.

Joshi.,V.K.; Kaushai,N.K.,(1995), Composition of apple pomace, standardization of pulp making, preparation and evaluation of apple pomace jam. Research and Industry, 40, 203-207.
Kertesz,Z. (1951), In: The pectic substances, Interscience : New York,. 528.

Marcon,M.V.,(2004), Extração e caracterização de pectinas obtidas de farinha de bagaço de maçã. Dissertação de Mestrado em Ciência e Tecnologia Universidade Estadual de Ponta Grossa, 128.

Marcon,M.V.; Vriesmann,L.C.; Wosiacki,G.; BeleskiCarneiro,E., (2005), Pectins from Apple Pomace. Polímeros: Ciência e Tecnologia, 15, 127-129.

McNeil,M., Darvill,A.G.; Albersheim,P. (1980), Structure of plant-cell walls 10 . Rhamnogalacturonan-I, a structurally complex pectic polysaccharide in the walls of suspension-cultured sycamore cells. Plant physiology, 66, 1128-1134.

Monsoor, M.A., Kalapathy, U., Proctor, A., (2001), Determination to polygalacturonic acid content in pectin extracts by diffuse reflectance fourier transform infrared spectroscopy. Food Chemistry, 74, 233-238.

Moorhouse,R., (2004), Ubiquitous hydrocolloid. Food Ingredients, 9, 24-30.

IAL. (1976). Métodos físicos e químicos para análise de alimentos. In-IAL. Normas Analíticas. 3 ed., Instituto Adolfo Lutz, São Paulo.

Minkov,S.; Minchev,A.; Paev,K., (1996), Modelling ot the hydrolysis and extraction of apple pectin, Journal of Food Engineering, 29, 197-113.

Paganini,C., Nogueira,A., Denardi,F., Wosiacki,G. (2004), Análise da aptidão industrial de seis cultivares de maçãs, considerando suas avaliações físico-químicas (dados da safra 2001/2002), Ciênc. agrotec., 28, 1336-1343

Rosenbohm, C., Lundt, I., Christensen, T.M.I.E.(2003), Chemically methylated and reduced pectins: preparation, characterization by ${ }^{1} \mathrm{H} \quad \mathrm{NMR}$ spectroscopy, enzymatic degradation and gelling properties. Carbohydrate Research, 338, 637

Schemin,M.H.C.; Fertonani,H.C.R.; Waszczynskyj,N,; Wosiacki,G., (2005), Extraction of pectin from apple pomace. Brazilian Archives of Biology and Technology, 28, 259-266 